\title{
"Social reconciliation and the role of the historical method as tool for transitional justice"
}

\author{
Cira Palli-Aspero \\ Transitional Justice Institute - Ulster University
}

\begin{abstract}
In the aftermath of repressive political systems or periods of extreme violence, societies are often rooted in a complex ground of competing narratives about what happened and who is to be held responsible for the crimes committed, transforming the past in a much-contested space. Which might represent an obstacle for social and political reconciliation, and, thus, maintaining peace and ensuring guarantees for non-repetition. There is an increasing belief amongst scholars and practitioners that historical analysis of the conflict can contribute to the clarification of misconceived past events and provide recognition of the past atrocities. This understanding fits into a broader debate around the growing field of historical dialogue, which in conflict/post-conflict contexts is seen as a tool to understand the formation of historical narratives and their influence on the political and social structures (Barkan 2015; Strömbom 2017). The study is to investigate what is the role of the historical method as truth-seeking mechanism within transitional justice. The research method, based on interpretative document analysis through hermeneutic approach, focuses mainly on two elements. On the one hand, the creation of a database that compiles 41 cases which illustrate different experiences in which historical analysis is used as a method of inquiry. On the other, the study of the Historical Memory Group, later the National Centre for Historical Memory, in Colombia as illustrative case to gain a more detail insight on the potential of the historical method within transitional justice. I will present the results extracted from the cases analysed in the database and the perceptions to the potential role of HCC within the transitional justice strategy.
\end{abstract}

Keywords: History; Historical clarification commissions; Historical dialogue;

\section{References:}

Barkan, E. (2015). "Historical Dialogue: Beyond Transitional Justice and Conflict Resolution" (Ch.10.). In Neumann, K., and Thompson, J. (eds.) (2015). Historical Justice and Memory. Critical Human Rights. University of Wisconsin Press. USA.

Strömbom, L. (2017). "Revisited Pasts: Memory and Agency in Intractable Conflicts". Dialogues on Historical Justice and Memory Network. Working Paper Series n.13 